\title{
Food Safety Training for Food Handlers in the Canteen Elementary School, Yogyakarta
}

\author{
Dyah Suryani, ${ }^{1,2}$ Adi Heru Sutomo, ${ }^{2}$ Abu Tholib Aman, ${ }^{2}$ Suyitno ${ }^{3}$ \\ ${ }^{1}$ Faculty of Public Health, Universitas Ahmad Dahlan, Yogyakarta, Indonesia, \\ ${ }^{2}$ Faculty of Medicine, Public Health and Nursing, Universitas Gadjah Mada, Sleman, Indonesia, \\ ${ }^{3}$ MPHM, ASEAN Institute for Health Development, Mahidol University, Phutthamonthon, Thailand
}

\begin{abstract}
The knowledge in terms of food security affects the attitude that can influence the practice. A low level of knowledge can increase the prevalence of food-borne disease, especially among children. This study aimed to examine the effect of food security training on increasing knowledge, attitude, and practice. This study retrieved 87 food handlers (intervention $=43$, control=44) from 60 school canteens in Yogyakarta city, 2018. The quasi-experimental study used a non-equivalent design control group by using pretest and posttest. The given intervention was an interactive speech, presentation, and food security module. The statistical test used in this study were normality tests and independent $t$ test. The majority of respondents for intervention and control groups were female (93\% each). A significant increase in knowledge, attitude, and practice has been found after training ( $\mathrm{p}$ value $<0.05$ ). There was no difference in knowledge, attitude, and practice among the control group ( $p$ value $>0.05$ ). This research finding the intervention effectively increases the knowledge, creates the positive, and increases food handlers and consumers' food security practices in the school. Public health providers should design health programs to conduct practical food security training. It is to be conducted continuously for food handlers in the school canteen. They need to remind them that knowledge is essential. Related stakeholders like schools should also provide adequate sanitation facilities and increasing supervision at the school canteen.
\end{abstract}

Key words: Food handlers, food safety training, school canteen

\section{Pelatihan Keamanan Pangan untuk Penjamah Makanan di Kantin Sekolah Dasar, Yogyakarta}

\begin{abstract}
Abstrak
Pengetahuan dalam hal ketahanan pangan memengaruhi sikap yang dapat memengaruhi praktik. Tingkat pengetahuan yang rendah dapat meningkatkan prevalensi penyakit bawaan makanan, terutama pada anak. Penelitian ini bertujuan menguji pengaruh pelatihan ketahanan pangan terhadap peningkatan pengetahuan, sikap, dan praktik. Penelitian ini mengambil 87 penjamah makanan (intervensi=43, kontrol=44) dari 6o kantin sekolah di Kota Yogyakarta tahun 2018. Penelitian kuasi eksperimental menggunakan desain kelompok kontrol nonekuivalen dengan menggunakan pretest dan posttest. Intervensi yang diberikan adalah pidato interaktif, presentasi, dan modul ketahanan pangan. Uji statistik yang digunakan dalam penelitian ini adalah uji normalitas dan uji $\mathrm{t}$ independen. Responden kelompok intervensi dan kontrol mayoritas berjenis kelamin perempuan (masing-masing 93\%). Peningkatan signifikan pada pengetahuan, sikap, dan praktik ditemukan setelah pelatihan ( $<<0,05)$. Tidak ada perbedaan pengetahuan, sikap, dan praktik antara kelompok kontrol ( $>>0,05)$. Penelitian ini menemukan bahwa intervensi efektif untuk meningkatkan pengetahuan, menciptakan sisi positif, dan meningkatkan praktik ketahanan pangan antara penjamah makanan dan konsumen di sekolah. Petugas kesehatan masyarakat harus merancang program kesehatan untuk melakukan pelatihan ketahanan pangan yang efektif untuk dilakukan secara terus menerus bagi penjamah makanan di kantin sekolah, mengingatkan mereka tentang pengetahuan yang diberikan untuk setiap sesi dan pemangku kepentingan terkait seperti sekolah juga harus menyediakan fasilitas sanitasi yang memadai dan meningkatkan pengawasan di kantin sekolah.
\end{abstract}

Kata kunci: Kantin sekolah, pelatihan keamanan pangan, penjamah makanan

Received: 15 September 2020; Revised: 6 February 2021; Accepted: 8 April 2021; Published: 30 April 2021

Correspondence: Dyah Suryani. Faculty of Public Health, Ahmad Dahlan University. Jln. Prof. Dr. Soepomo, S.H., Yogyakarta 55164, Yogyakarta Special Region, Indonesia. E-mail: dyah.suryani@ikm.uad.ac.id 


\section{Introduction}

Diseases and infections caused by contaminated food (foodborne disease) remain a threat to public health globally. ${ }^{1}$ The World Health Organization (WHO) reported one in ten people become sick because of foodborne disease. More than 91 million people in developing countries are affected even though several types of research and intervention towards food security have been conducted. ${ }^{2}$ Awareness of food safety remains a significant problem among consumers in both developed and developing countries.3.4 However, foodborne diseases are more common in developing countries due to poor hygiene sanitation, lack of clean water, inappropriate food storage facilities, and lack of food safety education. ${ }^{5}$

Food handlers and consumers take the most crucial role in foodborne disease outbreaks due to the mishandling of preparation, processing, and store food. ${ }^{6}$ Many factors influence foodborne diseases in developing countries that, if handled properly, can reduce the incidence of this disease. ${ }^{1}$ In Jordanian, there is a low level of knowledge in food safety among food handlers and customers. ${ }^{7}$ Inadequate knowledge about food safety, awareness, and practice among consumers, lack of government regulations, and food safety initiatives have been reported in Cameroon. ${ }^{8}$

The improvement of food safety practices could be given by training, which is the most widely used. ${ }^{9}$ The 2018 Riskesdas results showed that the prevalence of diarrhea based on diagnosis by health professionals and diagnosis based on symptoms for all age groups in Yogyakarta city was $6.11 \%$ and $8.47 \%$. The prevalence of diarrhea based on health professionals' diagnosis in the under-five age group was $8.47 \%$, while for schoolage children (5 to 14 years), it was 6.38 percent. $^{10}$ The proper and standardized cooking process and food and good personal hygiene will protect against foodborne diseases among children in school-age. ${ }^{11}$ The study's primary background is the importance of training to improve the knowledge, attitude, and practice among food handlers. This study aimed to compare the level of knowledge, attitude, and practice between the trained and control groups among food handlers in the elementary school canteen in Yogyakarta.

\section{Methods}

This study is quasi-experimental research with a non-equivalent control group design by pretest and post-test. The pretest was done using a questionnaire to determine the level of knowledge and attitude of food handlers and the checklist table to inspect their behavior during food processing. This research got ethical clearance from the Medical and Health Research Ethics Committee (MHREC) Faculty of Medicine, Public Health, and Nursing, Universitas Gadjah Mada (Certificate approval No. KE/FK/297/EC/2017).

The sample of this study was 87 food handlers from 60 elementary schools in Yogyakarta. Notably, the sample was divided into two groups consisting of 43 food handlers who were become intervened and 44 others who became control groups.

The dependent variable of this study was food security. The independent variables were knowledge, attitude, and practice. The questionnaire used in this study is consisting of three parts: demographic characteristics of respondents (5 questions), knowledge of food security (11 questions), attitude in terms of food security (22 questions). The questionnaire has been validated and passed the reliability test by 38 food handlers in elementary school in Bantul regency. The checklist point (11 items) has been made to observe by the research assistant directly following each step during food processing.

The questions related to knowledge consisted of favorable and unfavorable questions with true or false choices. The questions related to attitude consisted of favorable and unfavorable, agree, disagree, and disagreeable choices. The point in the checklist of practices during food processing was adopted from the Regulation of Minister of Health Republic of Indonesia Number 1096 in 2011 with yes (if related) and no (if did not relate) choices. The respondents were informed that those questionnaires are not to grade their knowledge of food security because all of the information is secret. The respondents have been signed informed consent to ensure their participation. This study's intervention, namely food security training, has been done for one month in collaboration with the District of Health Office in Yogyakarta city. The training used interactive speaking with presentation and module of food security (four parts: introductions, food security and food-borne disease, food and drink hygiene sanitation, and hazard analysis critical control point (HACCP).

The data were tested for normalization then examined using an independent $t$ test with 
a significant level $a<0.05$. Each variable has been tested by a paired $t$ test and independent $\mathrm{t}$ test using Stata software for data science and statistical analysis.

\section{Results}

Demographic characteristic of respondents in this study describing by age, sex, educational level, participation in training, and duration of work) was presented in Table 1 .

Table 1 describes the mean age of the intervention and control group, which is almost the same by $42.23 \pm 8.315$ and $42.00 \pm 7.728$, respectively. Intervened respondents were aged
23 to 60 years, and the controlled respondents were age 20 to 56 years. Regarding the sex, most respondents for the intervention and control groups were female (93\% each). More than half of them graduated from senior high school, $65.1 \%$ and $72.7 \%$, respectively. In terms of participating in food security training, more than half of them, both for intervention and control group, had had food security training. Around half of the respondents in this study have been work as food handlers varied from o to 5 years, particularly $55.8 \%$ for the intervention group and $50.0 \%$ for the control group.

Table 2 shows the significant differences between pre and post-test for intervention groups

Table 1 Demographic Characteristic of Respondents

\begin{tabular}{|c|c|c|c|c|}
\hline \multirow{2}{*}{ Characteristics } & \multicolumn{2}{|c|}{ Intervention } & \multicolumn{2}{|c|}{ Control } \\
\hline & $\mathrm{n}=43$ & Percentage & $n=44$ & Percentage \\
\hline \multicolumn{5}{|l|}{ Age } \\
\hline Mean & \multirow{2}{*}{\multicolumn{2}{|c|}{$\begin{array}{c}42.23 \pm 8.315 \\
23-60\end{array}$}} & \multicolumn{2}{|c|}{$42.00 \pm 7.728$} \\
\hline Median (min-max) & & & & -56 \\
\hline \multicolumn{5}{|l|}{ Sex } \\
\hline Female & 40 & 93 & 40 & 93 \\
\hline Male & 3 & 7 & 4 & 7 \\
\hline \multicolumn{5}{|l|}{ Level of education } \\
\hline Elementary school & 4 & 9 & 3 & 7 \\
\hline Junior high school & 7 & 17 & 5 & 11 \\
\hline Senior high school & 28 & 65 & 32 & 723 \\
\hline University & 4 & 9 & 4 & 9 \\
\hline \multicolumn{5}{|c|}{ Participating in food handler training } \\
\hline No & 14 & 33 & 15 & 34 \\
\hline Yes & 29 & 67 & 25 & 66 \\
\hline \multicolumn{5}{|l|}{ Duration of work (year) } \\
\hline $0-5$ & 24 & 56 & 22 & 50 \\
\hline $6-10$ & 10 & 24 & 13 & 30 \\
\hline $11-15$ & 7 & 16 & 2 & 4 \\
\hline $16-20$ & o & o & 6 & 14 \\
\hline $21-25$ & 1 & 2 & 1 & 2 \\
\hline $26-30$ & 1 & 2 & o & o \\
\hline
\end{tabular}

Table 2 Mean Differences of Knowledge between Intervention and Control Group

\begin{tabular}{|c|c|c|c|c|c|c|}
\hline \multirow{2}{*}{ Variables } & \multirow{2}{*}{ Pre-test } & \multirow{2}{*}{ Post-test } & \multirow{2}{*}{$\begin{array}{c}\text { Mean } \\
\text { (Pre-Post) }\end{array}$} & \multicolumn{2}{|c|}{$95 \% \mathrm{CI}$} & \multirow[b]{2}{*}{$\mathbf{p}$} \\
\hline & & & & Lower & Upper & \\
\hline Control $(n=44)$ & 9.61 & 9.66 & 0.045 & -0.413 & 0.504 & 0.842 \\
\hline Intervention $(\mathrm{n}=43)$ & 9.07 & 10.05 & 0.976 & 0.539 & 1.414 & 0.000 \\
\hline \multicolumn{3}{|c|}{$\begin{array}{l}\text { The mean differences between control and } \\
\text { intervention group }\end{array}$} & -0.931 & -1.557 & -0.306 & 0.004 \\
\hline
\end{tabular}


Table 3 Mean Differences of Attitude between Intervention and Control Group

\begin{tabular}{|c|c|c|c|c|c|c|}
\hline \multirow{2}{*}{ Variables } & \multirow{2}{*}{ Pre-test } & \multirow{2}{*}{ Post-test } & \multirow{2}{*}{$\underset{\text { (Pre-Post) }}{\text { Mean }}$} & \multicolumn{2}{|c|}{$95 \% \mathrm{CI}$} & \multirow[b]{2}{*}{$\mathbf{p}$} \\
\hline & & & & Lower & Upper & \\
\hline Control $(n=44)$ & 77.86 & 78.66 & 0.795 & -2.538 & 4.129 & 0.633 \\
\hline Intervention $(\mathrm{n}=43)$ & 73.69 & 79.67 & 5.977 & 3.231 & 8.722 & 0.000 \\
\hline \multicolumn{3}{|c|}{$\begin{array}{l}\text { The mean differences between control and } \\
\text { intervention group }\end{array}$} & -5.181 & -9.448 & -0.915 & 0.018 \\
\hline
\end{tabular}

Table 4 Mean Differences of Practice between Intervention and Control Group

\begin{tabular}{|c|c|c|c|c|c|c|}
\hline \multirow{2}{*}{ Variables } & \multirow{2}{*}{ Pre-test } & \multirow{2}{*}{ Post-test } & \multirow{2}{*}{$\begin{array}{c}\text { Mean } \\
\text { (Pre-Post) }\end{array}$} & \multicolumn{2}{|c|}{$95 \% \mathrm{CI}$} & \multirow[b]{2}{*}{$\mathbf{p}$} \\
\hline & & & & Lower & Upper & \\
\hline Control $(n=44)$ & 9.64 & 9.68 & 0.045 & -0.639 & 0.729 & 0.894 \\
\hline Intervention $(\mathrm{n}=43)$ & 9.44 & 10.30 & 0.860 & 0.571 & 1.149 & 0.000 \\
\hline \multicolumn{3}{|c|}{$\begin{array}{l}\text { The mean differences between control and } \\
\text { intervention group }\end{array}$} & -0.815 & -1.554 & -0.076 & 0.031 \\
\hline
\end{tabular}

compared with the control group. After trained for one month, the knowledge of intervention respondents increases 0.0976 while the control respondents are only 0.045 . It can be concluded that the food security training is significant to increase the knowledge of food handlers ( $\mathrm{p}$ value $=0.004)$.

Table 3 explains the mean differences in the attitude of respondents before and after given food security training. For the control group, the mean is 0.795, and for the intervention group, the mean is 5.977. It can be concluded that the food security training is strongly significant to increase the attitude of food handlers ( $p$ value $=0.018$ ).

The practice of food security by respondents before and after training shows significant value (Table 4). The mean for control groups is 0.045 and for the intervention groups is 0.860 . Overall, the food security training is significant to increases the practice of food security of food handlers ( $\mathrm{p}$ value $=0.031)$.

\section{Discussion}

The $\mathrm{t}$ test result revealed that knowledge was a significant intervention to increase the knowledge of food security. The food handlers in the school canteen were required to understand the prevention of food contamination to ensure the food is proper to consume. Food handlers need to have knowledge and skill to produce hygiene food..$^{12}$ This study is in line with the previous study, which stated that training as an intervention could increase food handlers' knowledge. ${ }^{13}$ The training is an effective model to increase the understanding of food handlers about food security.$^{14}$ It is essential to have proper practices, so training is needed continuously for food handlers. ${ }^{15}$ The training in this study consisted of the knowledge of food processing and the prevention of contaminated food and ensure the food handlers have their proper knowledge to fulfill food hygiene requirements. ${ }^{16}$

Attitude is the scale of people to evaluate the strength and weakness of the practice. ${ }^{17}$ The positive attitude is needed to transform knowledge to be proper practices, and it can be a mediator between knowledge and practice. ${ }^{18}$ This study found that training significantly increased the attitude of food handlers. This result is supported by the previous study in Lebanon that reported intervention can positively improve attitude through food security. ${ }^{13}$ Attitude is an essential factor besides knowledge for indicating the tendency of decreasing food-borne disease. The excellent attitude of food handlers will lead to the safe food serving which is consumed. The study in South Africa also found the same result, the education and training about food security must be given to food handlers to strengthen their knowledge, attitude, and skill so the outbreak can be prevented. ${ }^{19,20}$ 
The result of this study found that the practice of food security can be increased by training. Children are one vulnerable age group. ${ }^{21}$ To prevent foodborne diseases among children, food security is essential to ensure healthy food for children. ${ }^{22}$ The finding in this study is supported by the study in Turkey, which found the training is essential in increasing food handlers' food security practice. ${ }^{23}$

Food security training is an effective model to increase knowledge which the basic to implement the proper hygiene attitude. ${ }^{24}$ The association between knowledge, attitude, and practice is also reported by other studies in Malaysia, Nigeria, and India. ${ }^{13,25,26}$ The food security practice can be increased by training food handlers. The refreshment of training is also needed to train and renew their skill. The duration of training needs to be shorter, no more than two weeks respectively. ${ }^{26}$

From the findings, there were two important issues for public health programs; 1) public health providers should design health programs to conduct effective food security training is to be conducted continuously for food handlers in the school canteen and remind them about the given knowledge for each session. 2) related stakeholders like school should also provide adequate sanitation facilities and Increasing supervision at the school canteen.

\section{Conclusion}

The result of this research finding the intervention (training: interactive speech, presentation, and food security module) is effective to increase the knowledge, create the positive and increase the food security practices between food handlers and consumers in the school.

\section{Conflict of Interest}

The authors declare that there is no conflict of interest regarding the publication of this paper.

\section{Acknowledgments}

This study has been conducted by participants from the school canteen and food handlers.

\section{References}

1. Stratev D, Odeyemi OA, Pavlov A, Kyuchukova
R, Fatehi F, Bamidele FA. Food safety knowledge and hygiene practices among veterinary medicine students at Trakia University, Bulgaria. J Infect Public Health. 2017;10(6):778-82.

2. World Health Organization. WHO estimates of the global burden of foodborne diseases: foodborne disease burden epidemiology reference group 2007-2015. Geneva: World Health Organization; 2015.

3. Odeyemi OA, Bamidele FA. Harnessing the potentials of predictive microbiology in microbial food safety and quality research in Nigeria. Future Sci OA. 2016;(2):FSO91.

4. Odeyemi OA, Sani NA, Obadina AO, Saba CKS, Bamidele FA, Abughoush M, et al. Food safety knowledge, attitudes and practices among consumers in developing countries: an international survey. Food Res Int. 2019;116:1386-90.

5. Giritlioglu I, Batman O, Tetik N. The knowledge and practice of food safety and hygiene of cookery students in Turkey. Food Control. 2011;22(6):838-42.

6. Sani NA, Siow ON. Knowledge, attitudes and practices of food handlers on food safety in food service operations at the Universiti Kebangsaan Malaysia. Food Control. 2014;37:210-7.

7. Osaili TM, Jamous DOA, Obeidat BA, Bawadi HA, Tayyem RF, Subih HS. Food safety knowledge among food workers in restaurants in Jordan. Food Control. 2013;31(1):145-50.

8. Sneyd A. Cameroon: perspectives on food security and the emerging power footprint. Sustainability. 2014;6(4):1868-95.

9. Medeiros CO, Cavalli SB, Salay E, Proença RPC. Assessment of the methodological strategies adopted by food safety training programmes for food service workers: a systematic review. Food Control. 2011;22(8): 1136-44.

10. Badan Penelitian dan Pengembangan Kesehatan. Laporan Provinsi DI Yogyakarta Riskesdas 2018. Jakarta: Lembaga Penerbit Badan Penelitian dan Pengembangan Kesehatan; 2019.

11. Manalu HSP, Su'udi A. Kajian implementasi pembinaan pangan jajanan anak sekolah (PJAS) untuk meningkatkan keamanan pangan: peran dinas pendidikan dan dinas kesehatan kota. Media Penelit Pengemb Kesehat. 2016;26(4):249-56. 
12. Kamboj S, Gupta N, Bandral JD, Gandotra G, Anjum N. Food safety and hygiene: a review. Int J Chem Stud. 2020;8(2):358-68.

13. Dudeja P, Singh A, Sahni N, Kaur S, Goel S. Effectiveness of an intervention package on knowledge, attitude, and practices of food handlers in a tertiary care hospital of north India: a before and after comparison study. Med J Armed Forces India. 2017;73(1):4953 .

14. Zanin LM, da Cunha DT, de Rosso VV, Capriles VD, Stedefeldt E. Knowledge, attitudes and practices of food handlers in food safety: an integrative review. Food Res Int. 2017;100(Pt 1):53-62.

15. da Cunha DT, Braga ARC, de Camargo Passos E, Stedefeldt E, de Rosso VV. The existence of optimistic bias about foodborne disease by food handlers and its association with training participation and food safety performance. Food Res Int. 2015;75:27-33.

16. Seaman P. Food hygiene training: introducing the food hygiene training model. Food Control. 2010;21(4):381-7.

17. Bou-Mitri C, Mahmoud D, El Gerges N, Abou Jaoude M. Food safety knowledge, attitudes and practices of food handlers in Lebanese hospitals: a cross-sectional study. Food Control. 2018;94:78-84.

18. Ko WH. The relationship among food safety knowledge, attitudes and self-reported HACCP practices in restaurant employees. Food Control. 2013;29(1):192-7.

19. Al-Shabib NA, Mosilhey SH, Husain FM. Cross-sectional study on food safety knowledge, attitude and practices of male food handlers employed in restaurants of
King Saud University, Saudi Arabia. Food Control. 2016;59:212-7.

20. Park SH, Kwak TK, Chang HJ. Evaluation of the food safety training for food handlers in restaurant operations. Nutr Res Pract. 2010;4(1):58-68.

21. Vlasin-Marty K, Ritter-Gooder P, Albrecht JA. Food safety knowledge, attitudes, and behaviors of Native American families with young children: a mixed methods study. J Racial Ethn Heal Disparities. 2016;3(4):71323.

22. Tutu BO, Hushie C, Asante R, EgyakwaAmusah JA. Food safety knowledge and selfreported practices among school children in the Ga West Municipality in Ghana. Food Control. 2020;110:107012.

23. Acikel CH, Ogur R, Yaren H, Gocgeldi E, Ucar M, Kir T. The hygiene training of food handlers at a teaching hospital. Food Control. 2008;19(2):186-90.

24. Gormley FJ, Rawal N, Little CL. Choose your menu wisely: cuisine-associated foodpoisoning risks in restaurants in England and Wales. Epidemiol Infect. 2012;140(6):9971007.

25. Abdul-Mutalib N, Abdul-Rashid M, Mustafa S. Knowledge, attitude, and practices regarding food hygiene and sanitation of food handlers in Kuala Pilah, Malaysia. Food Control. 2012;27(2):289-93.

26. Adesokan HK, Akinseye VO, Adesokan GA. Food safety training is associated with improved knowledge and behaviours among foodservice establishments' workers. Int $\mathrm{J}$ Food Sci. 2015;2015:328761. 